\title{
Age Discrimination and Early Retirement Policies: A Comparison of Labor Market Regulation in Canada and the United States
}

\author{
C T. Gillin \\ Ryerson University
}

Thomas R. Klassen

University of Toronto

digital.library.ryerson.ca/object/154

Please Cite:

Gillin, C. T., \& Klassen, T. R. (1995). Age discrimination and early retirement policies: A comparison of labor market regulation in Canada and the United States. Journal of Aging \& Social Policy, 7(1), 85-102.

doi:10.1300/J031v07n01 06

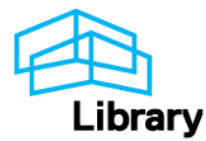




\title{
Age Discrimination and Early Retirement Policies: A Comparison of Labor Market Regulation in Canada and the United States
}

\author{
C. T. Gillin, MA \\ Ryerson Polytechnical University \\ Toronto, Ontario, Canada \\ Thomas R. Klassen, PhD \\ University of Toronto \\ Toronto, Ontario, Canada
}

Charles Talbot Gillin is Professor of Sociology at Ryerson Polytechnical University, 350 Victoria Street, Toronto, Ontario, Canada, M5B 2K3. His interest in law and aging developed while on sabbatical at the University of Baltimore (1991-92). Thomas R. Klassen is Senior Analyst with the Ontario Ministry of Finance, and is associated with the Department of Sociology at the University of Toronto. His research interests include labor market adjustment and the role of formal organizations in policy formation.

The authors wish to thank Janet Atkinson, Robin Haley-Gillin, Jeff K. Kehoe, and the anonymous referees for their helpful comments, criticisms, and suggestions.

Professor Gillin can be contacted care of the Department of Sociology, Ryerson Polytechnical University, 350 Victoria Street, Toronto, Ontario, Canada M5B 2K3; e-email: TGILLIN@hermes.acs.ryerson.ca; FAX: (416) 979-5273.

Journal of Aging \& Social Policy, Vol. 7(1) 1995

(c) 1995 by The Haworth Press, Inc. All rights reserved. 
ABSTRACT. As public policy issues, mandatory retirement and age discrimination are approached differently in Canada and the United States. The legal frameworks, enforcement procedures, and judicial decisions are distinct in the two jurisdictions. The United States, unlike Canada, has specific legislation to protect the rights of older workers, and has a centralized enforcement system. The differences between the two countries are accounted for by the greater emphasis on individual rights in the United States and on communitarianism in Canada. The different policy choices of each society highlight the tensions inherent in North American labor markets. The United States seems to be in a better position to shift toward a labor-management policy which encourages older workers to remain in the workforce.

North American governments regulate the labor market in a variety of ways. Governments influence or determine many aspects in the employer-employee relationship, including minimum compensation, maximum hours, collective bargaining, and other employment standards. Of key importance for older workers is regulation of age discrimination and mandatory retirement. These social policy issues are controversial because of the need to balance the rights of older individuals (to remain employed) with those of employers (to have an efficient workforce) and the broader society (to regulate unemployment).

This article compares Canada and the United States with regard to mandatory retirement and age discrimination policies, legislation, enforcement and adjudication. Three questions animate the comparison: Are there significant differences between Canada and the United States with respect to mandatory retirement and age discrimination policy and enforcement? What explains the differences between the two countries in how these issues are treated? What can be learned from the comparison of Canada and the United States that might aid in the debate on public policy vis-á-vis mandatory retirement and age discrimination?

These questions are important for a number of reasons. Fernando Torres-Gil (1992) argues that conflicting generational claims, population diversity, and increasing longevity are three major forces of population aging that will influence social policy in the immediate future. Generational claims can lead to conflict over limited resources. Generational differences can also be exacerbated by population diversity; simply put, greater heterogeneity of both the elderly 
and the working population will mean increased pressures for policy changes. Moreover, increased longevity threatens income security because of inflationary erosion of pensions and savings. Writing about the 1990s and beyond, Torres-Gil argues, "Income security will be about working and being able to work" (1992, p. 96).

A shift toward later retirement and facilitation of employment in later life could reduce stress on both public and private spending for older adults. Older workers, if viewed as a resource and offered retraining and flexible work opportunities, could reduce the fiscal burden on societies experiencing population aging (Moody, 1990). As a consequence, access to work and faimess in the workplace, including the issues of mandatory retirement and discrimination against older workers, will become increasingly important issues in Canada and the United States.

For the purposes of this article, mandatory retirement refers to an organization of the labor market that requires workers to withdraw their services at an arbitrary age. Age discrimination, on the other hand, refers to a broader category of social behavior in which age categories are used for the basis of a variety of employment decisions, for example, hiring, retraining, promoting, and firing.

\section{THE LEGAL FRAMEWORKS}

This section examines the legal frameworks in Canada and the United States. The Canadian Charter of Rights and Freedoms, which came into effect in 1982, grants every individual equality "before and under the law, and the right to equal protection and benefit of the law ... . without discrimination based on race, national or ethnic origin, colour, religion, sex, age or mental or physical disability" (Section 15 [2], emphasis added). These rights, however, are subject to "such reasonable limits prescribed by law as can be demonstrably justified in a free and democratic society" (Section 1).

Each jurisdiction in Canada (the federal and provincial governments) has a Human Rights Act whose purpose is to prevent discrimination in all matters coming under its jurisdiction. ${ }^{1}$ The various Human Rights Acts generally prohibit employers from refusing or terminating employment based on characteristics of individuals, 
including age, but also race, sex (gender), ethnic origin, sexual orientation, and so forth.

Quebec is the only province that has legislatively prohibited mandatory retirement by passing the Abolition of Compulsory Retirement Act in 1983. In Manitoba, a series of judicial interpretations of its Human Rights Act effectively abolished mandatory retirement by 1982 (Flanagan, 1985).

In the remaining Canadian jurisdictions, including the federal one, the Human Rights Acts do not outlaw mandatory retirement because of the manner in which age is defined. Some jurisdictions do not define or place an upper limit on age. In these jurisdictions, mandatory retirement can be challenged under the applicable $\mathrm{Hu}-$ man Rights Act. However, employers can justify mandatory retirement by reference to "one of the exemptions, for example, a bona fide occupational requirement" (Simon, 1988, p. 71). In the other jurisdictions, age is defined, for the purposes of the Act, to have an upper limit-65 years-at which time protection of the applicable Human Rights Act expires. ${ }^{2}$

In contrast to Canada, the United States provides specific legislation protecting older workers against age discrimination-including forced retirement-rather than relying upon more generic human rights legislation. The American cultural and legal tradition, as embodied in the U.S. Bill of Rights and subsequent constitutional amendments, emphasizes protection of individual rights. This spirit can be found in many pieces of federal legislation, notably civil rights legislation, including the Age Discrimination in Employment Act of 1967 (ADEA). Canada has no legislation comparable to the ADEA.

The purpose of the ADEA is to promote employment based on ability rather than age, to prohibit arbitrary age discrimination, and to help employers and employees meet the problems that arise from the impact of age on employment (P.L. 90-202, 29 U.S.C. 621 et seq.). The ADEA is a hybrid act, deriving substantive provisions from Title VII of the Civil Rights Act of 1964-which prohibits discrimination based on race, color, religion, sex, or national origin-but also from other pieces of legislation. ${ }^{3}$ Thus, while the ADEA's prohibition of ageism shares much in common with the prohibition of racism and sexism, the ADEA has some distinctive provisions (Eglit, 1981-1990, vols. 1-2; Kalet, 1990). 
Under the ADEA, age discrimination occurs if a covered organization uses age distinctions, makes employment decisions based on age, perpetuates systemic age discrepancies, or uses systems that have an unjust impact on older workers (Player, 1988). Coverage of the ADEA is limited to individuals 40 years of age and older, with limited exclusions of some high-level executives and policymakers. Other limitations of the legislation include: age criterion where it is a bona fide occupational qualification, the impact of age differentiation when it is based on reasonable factors other than age, and age as a part of a seniority system or employee benefit plan (Brown, 1989; Eglit, 1985).

Amendments to the ADEA have extended its reach to include government workers and American workers abroad employed by U.S. companies; amendments have also strengthened various provisions of the Act. Of particular interest here is that, in 1978, amendments revised the eligibility age to 70 for most workers and abolished mandatory retirement for most federal employees; then, in 1986, a further amendment eliminated mandatory retirement for most American workers.

In 1990, passage of the Older Workers Benefit Protection Act (OWBPA) reaffirmed the original congressional intent of the ADEA with regard to prohibiting age discrimination in employee benefit plans (P.L. 101-433, 29 U.S.C. 621 et seq.). While M. C. Harper (1994) raises concerns about the limitations of this legislation, he agrees that OWBPA generally furthers the consensus against age discrimination. Thus, while Canadian concern is focused on the issue of mandatory retirement, in the United States, mandatory retirement largely has been eliminated and the broader goal of eliminating age discrimination has a substantial legislative history.

\section{ENFORCEMENT PROCESSES}

Within Canada, each jurisdiction has a Human Rights Commission in one form or another which is responsible for investigating and, if necessary, ruling on human rights violations brought to its attention by individuals. The procedures of the Human Rights Commissions emphasize conciliation, beginning with informal procedures before formal complaints are filed. In 1992, less than 7\% (88) 
of complaints to the federal Human Rights Commission proceeded to the final step in the disposition process. Only a handful of those cases were appealed to the courts. Rulings can be appealed concluding with the Supreme Court of Canada, which has the power to interpret all legislation in Canada. In 1992, the Canadian Human Rights Commission received 52,000 inquiries and investigated a total of 1,300 complaints of which $11 \%$ concerned age discrimination (Canadian Human Rights Commission, 1993).

At the sub-federal level, Ontario is Canada's most populous province with a population of ten million, accounting for one third of the national population. In 1990-91, the Ontario Human Rights Commission investigated a total of 2,500 complaints. Only $7 \%$ of the complaints dealt with age discrimination, and half of those dealt with termination of employment (Ontario Human Rights Commission, 1993). The decentralized nature of the Canadian state is reflected in the fact that the Human Rights Commission of one province investigated more complaints than the national commission.

Within the American context, the Civil Rights Act, the ADEA, and other anti-discrimination legislation are interpreted and enforced by the federal Equal Employment Opportunity Commission (EEOC). For fiscal year 1991, the Commission received more than 44,200 charges under Title VII of the Civil Rights Act and more than 17,400 ADEA charges (General Accounting Office, 1992). The EEOC investigates and resolves these charges through 50 field offices in conjunction with state and local Fair Employment Practices Agencies, which also deal with issues of employment discrimination.

The Canadian and American figures are difficult to compare directly because of the decentralized character of the Canadian Human Rights Commissions. Furthermore, any comparison between the two countries must take into account a ten-fold population differential. Given that the number of age-related charges in the United States is more than one hundred times the number of similar complaints received at the federal level in Canada, we can assume that substantially more charges per capita are filed in the United States.

The most frequently alleged charge in the United States is improper discharge, making up more than a third of all ADEA charges and more than half of all litigations. Age discrimination is also often 
interrelated with minority and gender discrimination; such concurrent charges also account for more than a third of all charges filed (EEOC, 1991).

As in Canada, current U.S. enforcement procedures emphasize conciliation. A private party may not file an age discrimination lawsuit until the charge has first been filed with and investigated by the EEOC. The Commission may bring suit independently, without an individual charge being laid; but the agency must first attempt reconciliation (Kalet, 1990; Lynch, 1990). The emphasis upon reconciliation has continued with the Commission announcing in 1992 an alternative dispute resolution pilot project in four major cities (EEOC, 1992b). Only a very small number of charges actually become lawsuits. Based upon the most recent data available, in 1988, 106 lawsuits were filed-only one half of one percent of 24,440 ADEA charges received in the same year (EEOC, 1992a).

The effectiveness of the Commission in dealing with age discrimination charges has been a matter of some controversy. Lynch (1990) argues that the EEOC is effectively serving a diverse client base. Others are much less sanguine, as reflected in two Senate hearings on the subject (U.S. Senate, 1987, 1988).

Initially, one of the distinctive features of the ADEA was that it included a statute of limitations. Problems of enforcing the provisions of the Act within the statutory time frame led to the Senate hearings of 1987 and 1988 mentioned above. In 1988, the Senate learned that as many as 7,500 age discrimination cases had lapsed because they had run past the statute of limitations (U.S. Senate, 1988). That hearing resulted in corrective legislation being passed, twice to extend the statute of limitations (in 1988 and 1990) and, finally, in 1991 to amend the ADEA to eliminate the statute of limitations. ${ }^{4}$ The adequacy of enforcement remains a concern within the aging network (also see GAO, 1992).

\section{LEGAL DECISIONS}

During the past decade and a half, the Supreme Court of Canada has ruled on a number of cases dealing with mandatory retirement, which commenced as complaints to various Human Rights Commissions. In making its decisions the Court had to clarify whether 
mandatory retirement is a violation under the Canadian Charter of Rights and Freedoms.

In 1982, the Canadian high court ruled that for mandatory retirement to be judicially acceptable, employers must demonstrate that it constitutes a bona fide occupational qualification and requirement (Ontario Human Rights Commission v. Borough of Etobicoke 132 D.L.R. (3rd) 14 [1982]). Furthermore, the Court asserted that "the proof of such objective reasons must meet very strict evaluation standards" (David, 1993, p. 23). On these grounds, the Court found that mandatory retirement of fire fighters at age 60 was unjustifiable.

More recent court decisions, however, illustrate a dramatically different type of reasoning for determining whether mandatory retirement requirements can be upheld. In 1990, the Court made two key decisions which outlined a different test for whether mandatory retirement is a violation of "Charter Rights." In McKinney, the Court found that mandatory retirement at 65 for university professors and librarians in Ontario was not unconstitutional. The prime reason provided was that mandatory retirement was fundamental to, and an accepted aspect of, the operation of the labor market and employeeemployer relations (McKinney v. University of Guelph 76 D.L.R. (4th) 545 [1990]). In Stoffman, the Court found that mandatory retirement at age 65 for doctors from hospitals is justifiable because only with the departure of older staff members can new vitality and perspectives be infused into hospitals (Stoffman v. Vancouver General Hospital 76 D.L.R. (4th) 700 [1990]). More recently, the Court again ruled that mandatory retirement for university faculty, while constituting discrimination, is constitutional (and hence upheld) because it provides opportunities for younger persons to enter the labor market (Dickason $v$. the University of Alberta and The Alberta Human Rights Commission 95 D.L.R. (4th) 439 [1992]).

The recent Canadian decisions make clear that the Canadian Supreme Court believes mandatory retirement confers societal benefits that outweigh the rights of individuals. The judgments explicitly show that the objectives of institutions, such as hospitals and universities (to hire recently trained staff), as well as larger societal concems (to provide opportunities to persons entering the labor force) take precedence over individual rights to continued employment. 
The decisions of the Court, however, were not unanimous and reflect fundamentally different legal philosophies on the Court, between those who view individual rights as paramount and those who view societal concerns as valid reasons for constraining individual rights. The latter group (currently the majority on the Court) perceives communitarian interests to outweigh individual rights. The decisions to date "will no doubt lead to further confusion in determining the scope and content of the [Charter's] equality guarantee" (Bur \& Kehoe, 1992, p. 500).

The grounds for legal action under American law are more specifically developed than is the case in Canada. In general, the ADEA requires employers to avoid using the age of their employees as the deciding factor in business decisions; however, the Act does not mandate any special treatment of older workers. By requiring employers not to discriminate against older workers, the law seeks to prevent arbitrary age discrimination.

While many age discrimination lawsuits are won, the plaintiffs carry a heavy burden: they must demonstrate by a preponderance of evidence that age was the crucial factor, and they carry the responsibility to define an alternative practice. Despite these burdens, the Rand Corporation's Institute for Civil Justice noted that in California, in 1988, 70 percent of wrongful dismissal cases were won (Coulson, 1990). Most of these cases were filed by middle managers or executives; thus, the intervention available to the average worker is in practice solely limited to the efforts of the Equal Employment Opportunity Commission.

The Commission was originally established to interpret and enforce Title VII of the Civil Rights Act of 1964, and the ADEA originally was enforced by the Department of Labor. When enforcement of the ADEA was transferred to the EEOC, the Commission generally sought to interpret the ADEA in a manner as consistent as possible with Title VII, despite the hybrid character of the ADEA. The Commission has not been entirely successful in this regard because the U.S. Supreme Court continues to be cautious in the extent to which it sees similarities between discrimination based on race and sex, on the one hand, and age, on the other.

The U. S. Supreme Court's approach to age discrimination cases has shifted over time. In 1971, the Court applied the notion of 
"disparate impact" to age discrimination; disparate impact refers to employment practices that are "fair in form but discriminatory in practice” (Griggs v. Duke Power Co., 401 U.S. 424, 1971). This decision led to a number of changes in employment practices; for example, height and weight restrictions, which had a disparate impact on women and some minorities, have been abandoned as have aptitude tests with little correlation to job requirements.

In 1988, the U.S. Court backed away from its 1971 decision. In Griggs (1971), the Court found that discriminatory practices had to be "indispensable" to a business to be justified. In 1988, the Wards Cove decision shifted the "business necessity" standard to "reasoned review" of business practices-a lower standard of scrutiny. Moreover, the case established that the employer's burden of proof would be modest, one of "production," not "persuasion" (Wards Cove Packing Co. v. Atonio (490 U.S. 642, 1988; also see Shanor \& Marcosson, 1990).

The language of the Court in Wards Cove is, in fact, similar to that found in the ADEA. Unlike Title VII of the Civil Rights Act, the ADEA only requires employers to show that business practices that have disparate impact are reasonable, rather than the stronger burden of business necessity.

A 1989 Supreme Court decision, concerning bona fide employee benefit plans, further limited the impact of the ADEA on business. During the preceding two decades, the ADEA had interpreted differences in benefits to younger and older employees to be unacceptable unless justified by an "equal benefit or equal cost" standard. 5 In Betts, the Supreme Court rejected this interpretation and held that differences are acceptable unless an "actual intent to discriminate" could be demonstrated (Public Employees Retirement System of Ohio v. Betts, 492 U.S. 158, 1989). The effect of this decision was that employee benefit plans that existed prior to the passing of the ADEA could not be held unlawful under the ADEA.

Canadian and U.S. courts have been focused on different issues in their judicial findings (mandatory retirement v. age discrimination). Nevertheless, a similar pattern of legal thought is found in the Canadian Court's reflections on mandatory retirement and in the U.S. Court's approach to age discrimination: an initially articulated 
broad philosophy becomes narrowed in subsequent decisions because of business considerations.

\section{RECENT POLICY AND LEGAL DIRECTIONS}

During the past decade in Canada relatively little progress has been made in protecting older workers, whereas, in the United States, aging issues have been more politically salient. The U.S. Senate Special Committee on Aging continues to play a critical role in monitoring existing policies and programs and in initiating new ones. In Canada, beginning in the mid-1980s, the passage of employment equity legislation could have provided an opportunity to protect against age discrimination, but the chance was ignored. In the United States, on the other hand, the ADEA has been amended regularly since 1967 to strengthen the law.

In the 1980s, a number of attempts were made in Canada to introduce legislation to ban mandatory retirement, but only in Quebec have tangible results been obtained. In the mid to late 1980 s, a number of jurisdictions conducted public reviews of mandatory retirement which concluded that governments should ban mandatory retirement by amending the Human Rights Acts. ${ }^{6}$ The advice of such public deliberations has not been acted upon by governments.

As well, during the 1980s and early 1990s, Employment Equity Acts were enacted in a number of Canadian jurisdictions to address systemic employment discrimination of some groups (women, persons with disabilities, persons of visible minority racial descent, and persons of native descent). A variety of organizations, including Human Rights Commissions, sought to have older workers protected under the employment equity legislation; however, without exception the legislation has not incorporated any reference to discrimination based on age. The reasons for political inaction require additional research, but partly appear to be related to the lack of societal consensus about mandatory retirement and existence of systemic age discrimination. Many fear that banning mandatory retirement would likely increase the already high rate of unemployment, especially among Canadian youth. This seems reasonable because the unemployment rate in Canada generally has been several percentage points higher than in the United States since the mid 1980s. 
In the absence of Canadian political action, some change is apparent in the treatment of age discrimination by Human Rights Commissions. In 1993, the Ontario Human Rights Commission ruled that a foreman at a production plant was unfairly dismissed at age 57 because of his age. ${ }^{7}$ In early 1994, the Commission established a record settlement when it ruled that a lawyer was unfairly dismissed at age 56 solely due to his age. ${ }^{8}$ Also in 1994 at the federal level, the Canadian Armed Forces' policy of mandatory retirement was successfully challenged under the Canadian Human Rights Act. ${ }^{9}$ These rulings are significant in that they illustrate movement away from the question of mandatory retirement toward age discrimination.

In the United States, despite its history of a more activist judiciary, the Court presently lacks the desire to extend to ageism the hardier legal repercussions against racism and sexism. Nonetheless, Congress and the EEOC seem to be moving slowly in that direction, as befits the stronger American commitment to individual rights.

If the EEOC is to attain its apparent goal of integrating enforcement procedures of the Civil Rights Act and the ADEA, the agency must rely upon Congress to further integrate the two laws. In 1990, at least one Congressional action moved in the direction of integration. Congress reversed the Court's decision in Betts by passing The Older Workers Benefit Protection Act-discussed earlier-which codified the "equal benefit or equal cost" standard into the ADEA. In effect, the Act protects the benefit plans of older workers except where reduction in benefits is justified by significantly higher costs.

\section{SUMMARY OF FINDINGS}

In answer to the first question posed by this article, we have found significant differences in the regulation of labor force participation of older workers in Canada and the United States. Canada's policies are narrowly defined, lack a base in specific legislation, are inconsistent across jurisdictions, and are decentralized in enforcement. U.S. policies, on the other hand, are based on specific legislation (ADEA) and are comparatively consistently enforced through a federal agency (EEOC). 
In Canada, issues concerning older workers are framed narrowly, with the policy and legal focus primarily on mandatory retirement. The Canadian concern is how to regulate the exit of older workers from the labor market at a predetermined age. In contrast, the U.S. focus is on discrimination against older workers in a way which is generally analogous to, though distinct from, racism and sexism. Mandatory retirement has been a subsidiary issue.

In Canada, with the exception of the provinces of Quebec and Manitoba, mandatory retirement is not outlawed. Furthermore, no specific legislation exists that prohibits discrimination against older workers. Any protection for such workers is subsumed in more general and broader legislation granting basic rights and freedoms. In the United States, age discrimination is explicitly defined and prohibited.

Canada's enforcement system is decentralized with provincial Human Rights Commissions having significant roles. In the United States, enforcement and administration, while complex because of the EEOC's arrangements with state and local Fair Employment Practices Agencies, is highly centralized. A comparison of the two systems indicates that the number of per capita age-related complaints is significantly higher in the United States than in Canada. The higher level of complaints would seem to be explained, at least in part, by the fact that a regulatory agency exists dedicated to enforcing antidiscrimination legislation.

\section{DISCUSSION AND CONCLUSIONS}

The second question posed by the article is, How can the differences between Canada and the United States be explained? Our general conclusion, reflecting the distinct histories of the two societies, is that Canada has a greater collectivist public policy, while U.S. policy reflects a stronger commitment to individual rights. This position is consistent with the view held by others that Canada has a more communitarian orientation, as reflected in its national health care system (Clark, 1993; Lipset, 1990).

Canada's communitarian approach is illustrated by its Supreme Court decisions, which place community economic interests above individual rights-despite Canada's Charter of Rights. From the perspective of the Canadian Supreme Court, older workers, as a group, 
must not be allowed to monopolize jobs, but must make room for younger workers. In the United States, the greater concern for the rights of individuals is illustrated by both legislative actions and judicial interpretations. Laws explicitly protect older workers from employment discrimination.

The general trend, as well as the differences, in Canadian legal rulings can be partially accounted for by the fact that the Canadian Charter of Rights and Freedoms is relatively new (1982) so that its interpretation is only beginning and "the distance travelled by the courts cannot yet be too far from the words of the Charter" (Bur \& Kehoe, 1992, p. 512). In the United States, the tradition of the Bill of Rights combined with specific legislation from the 1960 s means that age discrimination issues are more highly evolved than in Canada. Further research is required, especially in Canada, to delineate the forces that have impeded progress in extending protection to older workers. While beyond the scope of this article, it would be useful to compare the different political forces, as distinct from the political philosophies, at work in the two societies.

The third question that frames this article is, What can be learned by the comparison of Canada and the United States? This question particularly is relevant, because a more communitarian approach to a variety of policy problems is being debated in the United States (Bellah et al., 1985; Etzioni, 1991; The Yale Law Journal, 1988). It is ironic that Canadian communitarian ideals, which created a national health system, are used to justify age-based rationing of employment - a criterion that to date has been eschewed in allocating medical care. The parallel irony in the United States is that the individual's right to employment beyond an arbitrary age is protected, but there is no concomitant right to health care.

The capacity of "advanced" economies to achieve full employment seems finite. From the communitarian point of view (LaSelva, 1987), the right of older workers to continue working represents a loss of opportunity for the young in the labor force. This view, however, has been criticized as unjust (Drummond, 1988) because it arbitrarily shifts opportunities from one generation to another. Furthermore, women are particularly vulnerable in a labor market with mandatory retirement because of their greater longevity and diversity of career paths (Walker, 1990). ${ }^{10}$ From the perspective of 
individualism, the inherent rights of the person must not be compromised any more than is necessary.

The argument for redistributing resources between generations through forced retirements is not well supported in the literature. Mandatory retirement is a relatively recent social practice, only a century old; and its rationale seems more rooted in bias than in economic rationality (Butler, 1975; Levine, 1988). Recent U.S. studies show that public safety is not compromised if competency testing replaces age-based retirement decisions of police and fire fighters, and that retirement patterns of tenured faculty are unlikely to change significantly if retirement is no longer age-based (Edwards, 1993).

Restricting the labor-force participation of older Canadian workers is done in the name of increasing access to work for youth. Economically and socially, however, it may be necessary to encourage older workers to stay in the workforce longer. As older workers retire, whether or not by choice, a heavy burden is placed on the productive labor force to pay for programs that sustain the retired. As the number of retirements increases, so does the social and financial burden. One possible result will be increased generational tensions exacerbated by social and cultural differences between the generations (Torres-Gil, 1992).

In Canada, with its extensive social programs, policymakers likely will be pressured in the future to eliminate mandatory retirement in order to minimize the public costs of a large retired population. At the same time, a continuing high rate of unemployment will mean ongoing pressure to maximize job opportunities by maintaining mandatory retirement.

The United States and Canada are distinct societies, yet share much in common. Currently, while facing many of the same economic and social challenges, they have chosen different paths in the labor-force management of older workers. One society cannot be a model for another, but an analysis of these aging societies suggests that older workers must continue to share the productive efforts of society or (unwittingly) create unmanageable burdens on the public purse. Because of its tradition of individual rights expressed through such legislation as the ADEA, the United States seems to be in a better position to shift toward a labor-management policy that encourages older workers to remain in the labor market. 


\section{CANADIAN CASES CITED}

Canada (Attorney General) v. Martin et al. 72 F.T.R. 249 [1994].

Ontario Human Rights Commission v. Borough of Etobicoke 132 D.L.R. 3rd 14

[1982]; 1 SCR 202.

McKinney v. University of Guelph 76 D.L.R. 4th 545 [1990]; 3 SCR 229.

Stoffman v. Vancouver General Hospital 76 D.L.R. 4th 700 [1990]; 3 SCR 483.

Dickason $v$. the University of Alberta and The Alberta Human Rights Commission

95 D.L.R. 4th 439 [1992].

\section{U.S. CASES CITED}

Griggs v. Duke Power Co., 401 U.S. 424 (1971).

Public Employees Retirement System of Ohio v. Betts, 492 U.S. 158.

Wards Cove Packing Co., Inc. et al. v. Atonio et al., 490 U.S. 642 (1988).

\section{ENDNOTES}

1. An example of Canadian legislation is the Canadian Human Rights Act, RSC $1976-77$ c 33 sect. 3.

2. Mandatory retirement at an age lower than 65 can be challenged, and the employer must demonstrate that it is a bona fide occupational requirement.

3. Provisions of the ADEA also draw upon the Fair Labor Standards Act of 1938 and the Portal-to-Portal Pay Act of 1947.

4. The three pieces of legislation are the Age Discrimination Claims Assistance Act of 1988 (P.L. 100-283), the Age Discrimination Claims Assistance Amendments of 1990 (P.L. 101-504), and the Civil Rights Act of 1991 (P.L 102-166, sect. 115).

5. The EEOC had adopted this interpretation based upon a 1969 Department of Labor regulation (29 C.F.R. section 860.120).

6. For example, see the Report of the Ontario Task Force on Mandatory Retirement published in 1987.

7. Upon reaching the decision (in McKee and Hayes-Dana), the Ontario Human Rights Commission noted that "During tough economic times ... it becomes even more critical that employers respect their employees' human rights."

8. At nearly half a million dollars, the settlement against Ontario Hydro is considered to be the largest human rights settlement in Canada (Hall, 1994).

9. Madame Justice Tremblay-Lamer ruled, "Since age is not the best indicator of the level of fitness of [Canadian Armed Forces] members, it is not reasonable to exclude an entire sector of the Forces from employment solely on that basis." Canada (Attorney General) v. Martin et al. 72 F.T.R. 249, 269 [1994].

10. Madame Justice L'Heureux-Dube in her dissenting opinions highlights the particular vulnerability of women (McKinney, Jr. v. University of Guelph and Dickason $v$. University of Alberta). 


\section{REFERENCES}

Bellah, R.N., Madsen, R., Sullivan, W.M., Swidler, A., \& Tipton, S.M. (1985). Habits of the heart: Individualism and commitment in American life. Berkeley and Los Angeles: University of California Press.

Brown, R.N. (1989). The rights of older persons (2nd ed.). Carbondale, IL: Southern Illinois University Press.

Bur, D.F., \& Kehoe, J.K. (1992). Developments in constitutional law: The 1990-91 term. The Supreme Court Law Review [Canada], 3, 403-513.

Butler, R.N. (1975). Why survive? Being old in America. New York: Harper \& Row.

Canadian Human Rights Commission. (1993). Annual Report 1992. Ottawa: Minister of Supply and Services Canada.

Clark, P.G. (1993). Moral discourse and public policy in aging: Framing problems, seeking solutions, and "public ethics." Canadian Journal on Aging, 12(4), 485-508.

Coulson, R. (1990). Empowered at forty: How to negotiate the best terms and time of your retirement. New York: HarperBusiness.

David, H. (1993). Canada's labor market: Older workers need not apply. Ageing International, 20(3), 21-25.

Drummond, R.J. (1988). Comment on "Mandatory retirement: Intergenerational justice and the Canadian Charter of Rights and Freedoms" by Samuel LaSelva. Canadian Journal of Political Science, 21(3), 585-595.

Edwards, R. (1993). Mandatory retirement: Police, fire fighters and tenured faculty. Public Administration Review, 53(4), 404-408.

Eglit, H.C. (1981-1990). Age discrimination (Vols. 1-3). Colorado Springs, CO: Shepard's/McGraw-Hill, Inc.

Eglit, H.C. (1985). Age and the law. In R.H. Binstock \& E. Shanas (Eds.), Handbook of aging and the social sciences (2nd ed.), (pp. 528-53). New York: Van Nostrand Reinhold Company.

Etzioni, A. (1991). A responsive community: Collected essays on guiding deliberate social change. San Francisco: Jossey-Bass Publishers.

Flanagan, T. (1985). Policy-making by exegesis: The abolition of "mandatory retirement" in Manitoba. Canadian Public Policy, 11(1), 40-53.

General Accounting Office. (1992). Age employment discrimination: EEOC's investigation of charges under 1967 law. GAO/HRD-92-82. Gaithersburg, MD: Author.

Hall, J. (1994, May 14). Landmark hydro case reveals age bias is rife. The Toronto Star, p. B5.

Harper, M.C. (1993). Age-based exit incentives, coercion, and the prospective waiver of ADEA Rights: The failure of the Older Workers Benefit Protection Act. Virginia Law Review, 79(6), 1271-1344.

Kalet, J.E. (1990). Age discrimination in employment law (2nd ed.). Washington, DC: The Bureau of National Affairs, Inc.

LaSelva, S.V. (1987). Mandatory retirement: Intergenerational justice and the 
Canadian Charter of Rights and Freedoms. Canadian Journal of Political Science, 20(1), 149-162.

Levine, M.L. (1988). Age discrimination and the mandatory retirement controversy. Baltimore, MD: The Johns Hopkins University Press.

Lipset, S.M. (1990). Continental divide: The values and institutions of the United States and Canada. New York: Routledge.

Lynch, M.K. (1990). The Equal Opportunity Commission: Comments on the agency and its role in employment discrimination law. Georgia Journal of International and Comparative Law, 20, 92-103.

Moody, H.R. (1990). The policies of entitlement and the policies of productivity.

In S. Bass, E. Kutza, \& F. Torres-Gil (Eds.), Diversity in aging (pp. 129-149).

Glenview, IL: Scott, Foresman \& Company.

Ontario Human Rights Commission. (1993). Annual Report 1990-91. Toronto, Ontario: Queen's Printer for Ontario.

Ontario Task Force on Mandatory Retirement. (1987). Fairness and flexibility in retiring from work. Toronto, Ontario: Queen's Printer for Ontario.

Player, M.A. (1988). Employment discrimination law (Hombook Series, Student Edition). St. Paul, MN: West Publishing Co.

Shanor, C.A., \& Marcosson, S.A. (1990). Battleground for a divided court: Employment discrimination in the Supreme Court, 1988-89. The Labor Lawyer, 6, 144-82.

Simon, P.L. (1988). Employment law: The new basics. Don Mills, Ontario: CCH Canadian Limited.

Torres-Gil, F.M. (1992). The new aging: Politics and change in America. Westport, CT: Auburn House.

U.S. Equal Employment Opportunity Commission. (1992a). Combined Annual Report, Fiscal Years 1986, 1987, 1988. Washington, DC: Author.

U.S. Equal Employment Opportunity Commission. (1992b, May). News release.

U.S. Equal Employment Opportunity Commission. (1991). Testimony of Evan J. Kemp, Jr., Chairman, before the Select Committee on Aging, U.S. House of Representatives.

U.S. Senate, Special Committee on Aging. (1988). EEOC's performance in enforcing the Age Discrimination in Employment Act (100th Cong., 2nd sess.). Washington, DC: U.S. Government Printing Office.

U.S. Senate, Special Committee on Aging. (1987). Twenty years of the Age Discrimination in Employment Act: Success or failure? (100th Cong, 1st sess.). Washington, DC: U.S. Government Printing Office.

Walker, A. (1990). Ageism in the British Labor Market: The social creation of economic insecurity among older workers. In J. Habib \& C. Nusberg (Eds.), Rethinking worklife options for older persons (pp. 39-55). Jerusalem: JDCBrookdale Institute and Washington, DC: International Federation on Aging.

The Yale Law Journal Company. (1988). Symposium: The Republican civic tradition. The Yale Law Journal, 97, 1,439ff. 